\title{
ДЕЯКІ КЛІНІЧНІ АСПЕКТИ ЛІПІТЕНЗІї
}

\author{
๑Н. В. Пасєчко, Л. В. Радецька, Н. І. Ярема, А. О. Боб, І. В. Смачило, \\ М. Є. Гаврилюк, Т. І. Крицький, 3. П. Мандзій, Г. І. Осінчук
}

ДВНЗ «Тернопільський державний медичний університет імені І. Я. Горбачевського МОЗ України»

РЕзюМЕ. Метою дослідження $\epsilon$ оцінка ефективності сучасної антигіпертензивної терапії у поєднанні зі статинотерапією та урсодезоксихолевою кислотою (УДХК) у хворих з ліпітензією (артеріальна гіпертензія (АГ) та гіперхолестеринемія).

Матеріал і методи. Обстежено 36 пацієнтів із гіпертонічною хворобою (ГХ) ІІ стадії, 2-3 ступенів, та гіперхолестеринемією, яким на фоні терапії діфорсом, аторвакором, урсохолом проводили комплексне клінічне дослідження, моніторування артеріального тиску (АТ) та ліпідного метаболізму.

Результати. Результати моніторування свідчать про сприятливий вплив вказаного лікування на добовий профіль АТ: через 2 місяці терапії зареєстровано достовірне зниження середньодобового систолічного та діастолічного АТ. Під впливом аторвастатину та урсохолу поліпшилися показники ліпідного обміну, що проявлялось достовірним зниженням рівня загального холестерину та холестерину ліпопротеїдів низької щільності, тенденцією до зростання вмісту ліпопротеїдів високої щільності.

Висновки. У статті обґрунтовано поєднане використання антигіпертензивної терапії, статинотерапії та урсохолу у хворих з ліпітензією, особливо у клінічних випадках, при яких необхідно обмежити дозування статинів, з точки зору поліпшення прогнозу хворих на ГХ за рахунок синергізму антигіпертензивного та ліпідознижувального потенціалу і плейотропних ефектів цих препаратів, дія яких направлена на сповільнення прогресування ГХ і атеросклерозу.

КлючовІ словА: артеріальна гіпертензія; холестерин; ліпопротеїди.

Вступ. Ліпітензія - це сучасний термін, який описує адитивний вплив артеріальної гіпертензії та гіперхолестеринемії на ризик серцево-судинних захворювань (СС3). Згідно з епідеміологічними дослідженнями, понад 50 \% пацієнтів з АГ мають гіперліпідемію [1]. Однозначно, що збільшений артеріальний тиск та підвищений рівень холестерину мають синергічний несприятливий вплив на формування кардіоваскулярного ризику, що було підтверджено у великій кількості клінічних досліджень і ретроспективних аналізів [2]. Більше того, впливи високих показників АТ і холестерину $\epsilon$ адитивними, пришвидшують розвиток атеросклерозу та збільшують ризик виникнення інших патологічних станів серцево-судинної системи [3].

Дисліпідемія негативно впливає на ефективність антигіпертензивної терапії, тому застосування статинів (аторвастатину, розувастатину) $\epsilon$ невід'ємною частиною лікування ССЗ. Однак внаслідок розвитку ураження паренхіми печінки i гепатоцелюлярного некрозу, особливо при хронічному стеатогепатиті, багато пацієнтів не можуть тривалий час приймати статини. У цьому випадку може виявитись доцільним застосування препарату, що має багато властивостей, обумовлених численними механізмами його дії, що включають антихолестатичний, цитопротекторний, гіпохолестеринемічний, літолітичний, імуномодулювальний, антиапоптотичний ефекти. Таким препаратом $\epsilon$ урсодезоксихолева кислота (УДХК).
Мета роботи - проведення адекватної гіполіпідемічної терапії у пацієнтів з АГ та гіперхолестеринемією.

Матеріал і методи дослідження. Обстежено 36 пацієнтів з есенціальною АГ та гіперхолестеринемією. У 58 \% хворих відзначали гіпертонічну хворобу II стадії, у протокольний комплекс їх лікування включено діфорс (препарат, який внесено у реєстр Першої Національної Соціальної Програми «3 турботою про співвітчизника»). Вік пацієнтів у середньому склав $(56,1 \pm 4,1)$ року, а індекс маси тіла $(27,1 \pm 4,1) \mathrm{kr} / \mathrm{M}^{2}$. Цікавими виявились гендерні особливості дослідження, а саме: 28 з 36 обстежуваних пацієнтів були жінками клімактеричного віку з підвищеним індексом маси тіла. Тривалість існування клінічно вираженої ГХ склала $(9,1 \pm$ $2,9)$ року, гіпертонічна хвороба II стадії 2 ступеня діагностована у 72,7 \% хворих, 3 ступеня - у $27,3 \%$. Середній рівень АТ на момент початку дослідження був наступним: систолічний - 178,2 мм рт. ст., діастолічний - 98,9 мм рт. ст. Контрольні вимірювання АТ проводили на 5, 10, 30, 60 дні лікування. Артеріальний тиск фіксували двічі на день (зранку і ввечері). Ефективність лікування оцінювали на підставі досягнутого цільового АТ згідно з Європейськими рекомендаціями з профілактики серцево-судинних захворювань ВООЗ (2013р.).

Хворих поділили на дві групи. Перша група (18 осіб), одночасно з базовою антигіпертензивною терапією (діфорс), одержувала аторвакор у дозі 10 мг і УДХК у вигляді препарату Урсохол 
Огляди літератури, оригінальні дослідження, погляд на проблему, ювілеї

(«Фармацевтична фірма «Дарниця») у дозі 1314 мг/кг на добу. Другу групу склали 18 хворих на АГ та гіперхолестеринемією, порівнянних за віком, статтю, характером клінічного перебігу захворювання, що одержували, окрім базової терапії, аторвакор у дозі 20 мг, без УДХК.

У крові хворих визначали основні показники обміну ліпідів і ліпопротеїнів: вміст загального холестерину (3XC), тригліцеридів (ТГ), ліпопротеїдів низької щільності (ЛПНЩ), ліпопротеїдів дуже низької щільності (ЛПДНЩ), ліпопротеїдів високої щільності (ЛПВЩ).

Усі визначення проведені на напівавтоматичному біохімічному аналізаторі «Cormay Plus» з використанням стандартних наборів фірми «Сormaу» (Польща).

Дослідження проведені на початку лікування і через 3 місяці спостереження. Отримані результати оброблені статистично із застосуванням різницевого методу і критерію Стьюдента.

Результати й обговорення. На антигіпертензивну терапію відповіли усі пацієнти. Вже через тиждень лікування вдалося домогтися суттєвого зниження показників АТ - систолічний АТ знизився у середньому на 32 мм рт. ст., а діастолічний АТ - на 14 мм рт. ст., у подальшому протягом 2 місяців спостерігалась поступова позитивна динаміка цих показників, яка дозволила у 78 \% пацієн-

\section{ЛІТЕРАТУРА}

1. Practice guidelines for the management of arterial hypertension of the European Society of Hypertension (ESH) and the European Society of Cardiology (ESC): ESH/ ESC Task Force for the Management of Arterial Hypertension / G. Mancia, R. Fagard, K. Narkiewicz [et al.] // J. Hypertens. - 2013. - Vol. 31. - P. 1925-1938.

\section{REFERENCES}

1. Mancia, G., Fagard, R., \& Narkiewicz, K. (2013). Practice guidelines for the management of arterial hypertension of the European Society of Hypertension (ESH) and the European Society of Cardiology (ESC): ESH/ESC Task Force for the Management of Arterial Hypertension. J. Hypertension, 31, 1925-1938. тів знизити офісний АТ до цільових рівнів (нижче 140/90 мм рт. ст.). Прихильність до лікування під час прийому препарату підвищилась у 74 \% пацієнтів. Після 2 місяців лікування у них відмічалось покращення загального стану, зменшення втомлюваності, порушень сну, головного болю, відсутність кризів, підвищення працездатності ( $n=31)$.

При проведенні аналізу біохімічних показників виявлене зниження 3ХС на 21-23\%, ТГ на 3941 \%, лПНЩ на 34-36 \% в обох групах, підвищення лПВЩ на 43 \% у першій групі й на $46 \%$ у другій групі, індекс атерогенності знизився на 13-14 \% як у першій, так і в другий групі.

Висновки. 1. Застосування статину та урсохолу в пацієнтів з ліпітензією $є$ безпечним і ефективним з метою корекції порушень обміну ліпідів.

2. Комбінація застосування урсохолу зі статином дозволяє знизити дозу статинів при збереженні вираженого гіполіпідемічного ефекту у пацієнтів з АГ в окремих клінічних випадках.

Перспективи подальших досліджень. Проблема артеріальної гіпертензії та гіперхолестеринемії у звичайній лікарській практиці повинна привернути особливу увагу до цього маркера стану пацієнтів. Ліпітензію слід розглядати як нову терапевтичну мішень, яка вимагає агресивного лікування з метою покращення прогнозу для даної категорії хворих.

2. Cholesterol lowering in intermediate-risk persons without cardiovascular disease / S. Yusuf, D. Phil, J. Bosch [et al.] // N. Engl. J. Med. - 2016. - Vol. 374. - P. 2021-2031.

3. Telmisartan, Ramipril, or both for patients of high risk of vascular events / S. Yusuf, P. Sleight, C. Anderson [et al.] // New Engl. J. Med. - 2008. - Vol. 358. - P. 1547-1559.

2. Yusuf, S., Phil, D., \& Bosch, J. (2016). Cholesterol lowering in intermediate-risk persons without cardiovascular disease. New Engl. J. Med., 374, 2021-2031.

3. Yusuf, S., Sleight, P., \& Anderson, C. (2008). Telmisartan, Ramipril, or both for patients of high risk of vascular events. New Engl. J. Med., 358, 1547-1559. 
Огляди літератури, оригінальні досліження, погляд на проблему, ювілеї

\title{
НЕКОТОРЫЕ КЛИНИЧЕСКИЕ АСПЕКТЫ ЛИПИТЕНЗИИ
}

\author{
ФН. В. Пасечко, Л. В. Радецкая, Н. И. Ярема, А. О. Боб, И. В. Смачило,
}

М. Е. Гаврилюк, Т. И. Крицкий, С. П. Мандзий, Г. И. Осинчук

ДВНЗ «Тернопольский государственный медицинский университет имени И. Я. Горбачевского МОЗ Украины»

РЕЗЮМЕ. Целью исследования является оценка эффективности современной антигипертензивной терапии В сочетании со статинотерапией и урсодезоксихолевой кислотой (УДХК) у больных с липитензией (артериальная гипертензия (АГ) и гиперхолестеринемия).

Материал и методы. Обследовано 36 пациентов с гипертонической болезнью (ГБ) ІІ стадии, 2-3 степени, и гиперхолестеринемией, которым на фоне терапии дифорсом, аторвакором, урсохолом проводили комплексное клиническое исследование, мониторинг артериального давления (АД) и липидного метаболизма.

Результаты. Результаты мониторинга свидетельствуют о благоприятном влиянии лечения на суточный профиль АД: через 2 месяца терапии зарегистрировано достоверное снижение среднесуточного систолического и диастолического АД. Под воздействием аторвакора и урсохола улучшились показатели липидного обмена, что проявлялось достоверным снижением уровня общего холестерина и холестерина липопротеидов низкой плотности, тенденцией к росту липопротеидов высокой плотности.

Выводы. В статье обосновано использование комбинированной антигипертензивной терапии, статинотерапии и урсохола у больных с липитензией, особенно в клинических случаях, при которых необходимо ограничить дозирование статинов, с точки зрения улучшения прогноза больных с ГБ за счет синергизма антигипертензивного и липидоснижающего потенциала и плейотропних эффектов этих препаратов, действие которых направлено на замедление прогрессирования ГБ и атеросклероза.

КЛЮЧЕВЫЕ СЛОВА: артериальная гипертензия; холестерин; липопротеиды.

\section{SOME CLINICAL ASPECTS OF LIPITENSION \\ @N. V. Pasechnko, L. V. Radetsky, N. I. Yarema, A. O. Bob, I. V. Smachilo, M. Ye. Gavrilyuk, T. I. Krytsky, S. P. Mandzii, G. I. Osinchuk I. Horbachevsky Ternopil State Medical University}

SUMMARY. The purpose of the study is to evaluate the effectiveness of modern antihypertensive therapy in combination with statin therapy and ursodeoxycholic acid (UDCA) in patients with lipentia (arterial hypertension (hypertension) and hypercholesterolemia).

Material and Methods. 36 patients with hypertonic disease (HD) of stage II, grade 2-3 and hypercholesterolemia were examined, which were performed a comprehensive clinical study, monitoring blood pressure (BP), and lipid metabolism on the basis of therapy by Difors, Atorvacor and Ursochol.

Results. The results of monitoring blood pressure indicate the beneficial effect of this treatment on the daily blood pressure profile: after 2 months of treatment was recorded a significant reduction in average daily systolic and diastolic blood pressure. Under the influence of atorvastatin and ursochol, lipid metabolism rates improved, which was manifested by a significant decrease in the level of total cholesterol and low density lipoprotein cholesterol, a tendency to increase the content of high density lipoprotein.

Conclusions. In this article the combined use of antihypertensive therapy, statin therapy and ursochol in patients with lipentia, especially in clinical cases in which it is necessary to limit the dosage of statins in terms of improving the prognosis of patients with HD due to the synergism of antihypertensive and lipid-lowering potential and pleiotropic effects of these drugs, the effect which is aimed at slowing the progression of HD and atherosclerosis, was justified.

KEY WORDS: arterial hypertension; cholesterol; lipoproteins. 